\title{
Modelling hatchability and mortality in muscovy ducks using automatic linear modelling and artificial neural network
}

\author{
A. Yakubu ${ }^{1, *}$, L. Dahloum ${ }^{2}$, A. J. Shoyombo ${ }^{3}$ and U. M. Yahaya ${ }^{1}$ \\ ${ }^{1}$ Department of Animal Science, Faculty of Agriculture, Nasarawa State University, \\ Keffi, Shabu-Lafia Campus, P.M.B. 135, Lafia, 950101 - Nigeria. \\ ${ }^{2}$ Laboratoire de Physiologie Animale Appliquée, Université Abdelhamid Ibn Badis, \\ 27000, Mostaganem - Algeria. \\ ${ }^{3}$ Department of Animal Science, Landmark University, Omu-Aran, Kwara State - Nigeria \\ *Corresponding E-mail: abdulmojyak@gmail.com
}

Received September 30, 2018; Accepted October 10, 2018

\begin{abstract}
ABSTRAK
Penelitian ini dilakukan untuk memprediksi daya tetas dan mortalitas entok di Negara Bagian Nasarawa, Nigeria. Data diperoleh dari total 119 peternak itik. Penelitian ini menggunakan automatic linear modelling (ALM) dan artificial neural network (ANN). Rata-rata ukuran flock adalah 9,84 $\pm 0,60$ per rumah tangga. Nilai rata-rata daya tetas yang diprediksi menggunakan ALM (8.66) dan JST (8.65) serupa dengan nilai yang diamati (8.66). Nilai rata-rata mortalitas yang diduga menggunakan ALM $(2,95)$ dan ANN $(3,03)$ sama dengan nilai yang diamati yang sebesar 2,95. Pengalaman dalam pemeliharaan itik, status pendidikan peternak, sumber stok dasar dan musim adalah variabel penting dalam pendugaan daya tetas menggunakan ALM dan ANN. Namun, pekerjaan utama, sumber stok dasar, pengalaman dalam pemeliharaan itik, pengelolaan lahan dan sistem manajemen adalah variabel penting yang secara otomatis terpilih untuk pendugaan mortalitas. Dugaan nilai sedang koefisien determinasi $\left(\mathrm{R}^{2}=0,422\right.$ vs 0,376$)$ dan adjusted $\mathrm{R}^{2}(0,417$ vs 0,371$)$ diperoleh untuk daya tetas dan mortalitas menggunakan ALM. Pola yang berbeda diperoleh pada ANN terkait dengan prediksi daya tetas $\left(\mathrm{R}^{2}=0,573\right.$ dan adjusted $\left.\mathrm{R}^{2}=0,569\right)$ dan mortalitas $\left(\mathrm{R}^{2}=0,615\right.$ dan adjusted $\left.\mathrm{R} 2=0,612\right)$. Informasi ini dapat membantu keputusan manajemen dalam memperoleh daya tetas dan mortalitas yang lebih baik pada ternak entok.
\end{abstract}

Kata kunci: entok, penampilan, neural network, regresi, Nigeria

\begin{abstract}
This study was embarked upon to predict hatchability and mortality rate of Muscovy ducks in Nasarawa State, Nigeria. Data were obtained from a total of 119 duck farmers. The automatic linear modelling (ALM) and artificial neural network (ANN) models were employed. The average flock size was $9.84 \pm 0.60$ per household. The predicted hatchability mean values using ALM (8.66) and ANN (8.65) were similar to the observed value (8.66). The predicted mortality mean values using ALM (2.95) and ANN (3.03) were also similar to the observed value of 2.95. Experience in duck rearing, the educational status of farmers, source of foundation stock and season were the variables of importance in the prediction of hatchability using ALM and ANN models. However, primary occupation, source of foundation stock, experience in duck rearing, land holding and management system were the important variables automatically selected for the prediction of mortality. Moderate coefficients of determination $\left(\mathrm{R}^{2}=0.422\right.$ vs 0.376$)$ and adjusted $\mathrm{R}^{2}(0.417$ vs 0.371$)$ estimates were obtained for hatchability and mortality using ALM. Different patterns were obtained under the ANN models as regards the prediction
\end{abstract}


of hatchability $\left(\mathrm{R}^{2}=0.573\right.$ and adjusted $\left.\mathrm{R}^{2}=0.569\right)$ and mortality $\left(\mathrm{R}^{2}=0.615\right.$ and adjusted $\left.\mathrm{R}^{2}=0.612\right)$. The present information may aid management decisions towards better hatchability and mortality performance in Muscovy ducks.

Kata kunci: Ducks, performance, neural network, regression, Nigeria

\section{INTRODUCTION}

In developing countries such as Nigeria, poultry production is largely managed under extensive free range or scavenging system, particular at villages and peri urban areas. Majority of the birds are reared at the rural level especially the indigenous stock, providing reservoir for the genetic conservation of the indigenous population. Poultry provide enormous opportunity to the rural poor from the generation of family income to employment opportunity (Yakubu, 2010; Yakubu et al., 2011; Johari et al., 2013). Lack of understanding of village poultry production system will normally impede design and implementation of poultry bird advancement program that will impact positively on the rural poor. It is pertinent to understand production system and constraint at this level in other to fashion policies that will enhance productivity of this system, thereby guaranteeing sustainable agriculture (Gómez et al., 2016).

Ducks ranked third among the various poultry species in Nigeria (Hassan and Mohammed, 2003), with population put at approximately 11 million and distribution cutting across all the agro-ecological zones of Nigeria particularly in village settings (NBS, 2012). In a section of the country, most farmers were found keeping Muscovy ducks on extensive sheds (Etuk et al., 2006). The advent of commercial fastgrowing and egg-laying strains of chickens has relegated to the background the relevance and relative contribution of indigenous poultry species such as chicken, duck, guinea fowl and pigeon to the internal animal protein production in Nigeria. This trend has adversely impacted on duck production as exemplified in its remarkable reduced population and dearth of empirical studies directed towards management and genetic improvement of this waterfowl in Nigeria (Yakubu, 2013; Oguntunji, 2013; Oguntunji and Ayorinde, 2014). The dwindling reproductive performance and high mortality rates of Muscovy ducks is a major concern as farmers income and protein intake are drastically affected. This may in the long run negatively affect food security and livelihood of the farmers. Hence, the need to identify the factors influencing the performance of the birds at the village level with a view to mapping out appropriate strategies to boost production.

The artificial neural network (ANN) is an alternative to the traditional regression statistical technique and a potential tool in poultry production for the modelling of performance data. ANN is a non-linear parametric model that mimics the processing mechanism of the human brain. There is increasing use of this algorithm to predict hatchability (Bolzan et al., 2008), growth (Yakubu et al., 2018a) and egg production (Ahmad, 2011). It has also been used to model disease occurrence (Akil and Ahmad, 2016).

There is dearth of literature on the use of robust models to forecast reproductive and mortality performance in Muscovy ducks in Nigeria. Therefore, this study aimed at predicting the reproductive and mortality rates of Muscovy ducks from some social-economic factors of smallholder farmers and performance characteristics using different statistical algorithms.

\section{MATERIALS AND METHODS}

\section{Description of Study Area}

The study was carried out in Nasarawa State, North Central Nigeria. It is located within the guinea savannah agro-ecological zone and lies on latitudes $7^{\circ} 52^{\prime} \mathrm{N}$ and $8^{\circ} 56^{\prime} \mathrm{N}$ and longitudes $7^{\circ}$ $25^{\prime} \mathrm{E}$ and $9^{\circ} 37^{\prime} \mathrm{E}$, respectively (Lyam, 2007). The three Senatorial Zones of Nasarawa South, Nasarawa North and Nasarawa West were covered.

\section{Sampling Techniques}

A total of 120 Muscovy duck farmers (40 per zone) were randomly sampled in selected villages of the study area, but data from 119 farmers were eventually used for analysis. Only farmers who were willing to participate in the exercise were interviewed.

\section{Data Collection Techniques}

Structured questionnaires were administered 
to the duck farmers including face-to-face interview. Information sought included the socioeconomic characteristics of the respondents, livestock ownership, flock sizes and structure, productive and reproductive performance indices, mortality rate, knowledge on health and other management practices.

\section{Statistical Analysis}

The categorical (using Chi-square) and continuous variables (using Means \pm S.E.) were subjected to descriptive statistics. The relationship between the response variables (hatchability and mortality number; each handled singly) and predictor variables were established using Automatic Linear Modelling (ALM) and Artificial Neural Network (ANN) algorithms. The hatchability parameter fitted was number of eggs hatched while mortality was assessed in terms of number of birds that died.

Age of farmers, sex, marital status, educational background, primary occupation, experience in poultry keeping, management system, health management practices (veterinary access, veterinary category, use of herbs) season of highest hatchability, age at first lay, access to credit, personal savings in financial institution and land holding were the input predictor variables fitted into the ALM to estimate reproductive success. Similarly, mortality rate was predicted from age of farmers, sex, marital status, educational background, primary occupation, experience in poultry keeping, management system, health management practices (veterinary access, veterinary category, use of herbs) season of highest mortality, age at first lay, access to credit, personal savings in financial institution and land holding. In each case, all the variables that were nominal were assigned as factors while all variables that were continuous were treated as covariates. Every other step was as described by LaFaro et al. (2015) and adopted by Yakubu et al. (2018).

All the explanatory variables of importance under ALM were fitted into the ANN model to predict hatchability and mortality number, respectively as described by LaFaro et al. (2015). Multilayer Perception (MLP) with BackPropagation network was used. The network was trained with $80 \%$ and tested (model validation) with $20 \%$ of the data set. Every other choice in the neural network was set to default (Yakubu et al., 2018a and b). SPSS (2015) was employed in both analyses.

\section{RESULTS}

The sex, marital status, education, primary occupation, access to credit and type of landholding varied significantly $(\mathrm{P} \leq 0.05 ; \mathrm{P} \leq 0.01)$ among the duck farmers (Table 1). As regards the continuous variables, the average age of respondents, family size and experience in duck keeping (years) were 44.54, 8.49 and 5.02.

The mean flock size was 9.84 comprising adult males (1.85), adult females (2.63), male growers (1.48), female growers (1.36), male ducklings (1.27) and female ducklings (1.33) (Table 2). Source of foundation, management system, breeding control, access to veterinary services, veterinary services category and use of herbs were significantly influenced $(\mathrm{P} \leq 0.01)$ (Table 3).

The average age of ducks at first lay (months), clutch number per year, egg number in a clutch, brooding length (weeks), egg number hatched in a clutch and mortality rate per annum were $5.51,2.84,9.87,4.68,8.66$ and 2.95, respectively (Table 4). While the highest hatchability was recorded in the wet season $(\mathrm{P} \leq$ $0.01)$, mortality rate was highest in the hot-dry season $(\mathrm{P} \leq 0.01)$.

The summary statistics of observed and predicted hatchability and mortality rate of Muscovy ducks are shown in Table 5. The predicted hatchability mean values using ALM (8.66) and ANN (8.65) were similar to the observed value (8.66). The Standard deviations were 1.80 (ALM), 2.12 (ANN) and 2.78 (observed), respectively. As regards mortality, the predicted mean values using ALM (2.95) and ANN (3.03) were also similar to the observed value of 2.95. The respective standard deviations were $1.72,2.14$ and 2.80 .

In the ALM model, experience in duck rearing and the educational status of farmers were the two significant variables in the prediction of hatchability out of the four important parameters Table 6). In the ALM model, primary occupation, source of foundation stock, experience in duck rearing, land holding and management system were the five significant variables automatically selected for the prediction of mortality (Table 7).

In ANN model, experience in duck rearing (0.387), source of foundation stock (0.320), educational status (0.148) and season of hatchability (0.144) were the four parameters of utmost importance in the prediction of hatchability (Table 8). 
Table 1. Socio Economic Characteristics of Muscovy Duck Keepers in Nasarawa State

\begin{tabular}{|c|c|c|c|}
\hline Characteristics & No $(\%)$ & Chi-square & P-value \\
\hline \multicolumn{4}{|l|}{ Categorical variables } \\
\hline \multicolumn{4}{|l|}{ Sex } \\
\hline Male & $46(38.7)$ & & \\
\hline Female & $73(61.3)$ & 6.126 & $0.013^{*}$ \\
\hline \multicolumn{4}{|l|}{ Marital Status } \\
\hline Single & $5(4.2)$ & & \\
\hline Married & $114(95.8)$ & & \\
\hline Widowed & $0(0.0)$ & 99.840 & $0.01 * *$ \\
\hline \multicolumn{4}{|l|}{ Education } \\
\hline None & $34(28.6)$ & & \\
\hline Primary & $29(24.4)$ & & \\
\hline Secondary & $44(37.0)$ & & \\
\hline Tertiary & $12(10.1)$ & 46.924 & $0.01 * *$ \\
\hline \multicolumn{4}{|l|}{ Primary Occupation } \\
\hline Livestock rearing & $30(25.2)$ & & \\
\hline Crop farming & $32(26.9)$ & & \\
\hline Trading & $44(37.0)$ & & \\
\hline Artisan & $12(10.1)$ & & \\
\hline Civil Service & $1(0.8)$ & 49.277 & $0.01 * *$ \\
\hline \multicolumn{4}{|l|}{ Access to Credit } \\
\hline No & $18(15.1)$ & & \\
\hline Yes & $101(84.9)$ & 57.891 & $0.01 * *$ \\
\hline \multicolumn{4}{|l|}{ Personal savings } \\
\hline No & $59(49.6)$ & & \\
\hline Yes & $60(50.4)$ & 56.588 & $0.927^{\text {ns }}$ \\
\hline \multicolumn{4}{|l|}{ Type of landholding } \\
\hline Individual ownership & $44(37.0)$ & & \\
\hline Communal farming system & $2(1.7)$ & & \\
\hline Rent & $1(0.8)$ & & \\
\hline Free occupation & $72(60.5)$ & 120.496 & $0.01 * *$ \\
\hline \multicolumn{4}{|l|}{ Continuous variables } \\
\hline & Mean & Standard error & \\
\hline Age of Respondent & 44.54 & 0.94 & \\
\hline Household size & 8. 49 & 0.30 & \\
\hline No of wives & 1.36 & 0.09 & \\
\hline No of male children & 3.35 & 0.16 & \\
\hline No of female children & 2.50 & 0.18 & \\
\hline No of dependants & 0.43 & 0.08 & \\
\hline Experience in duck keeping (years) & 5.02 & 0.41 & \\
\hline
\end{tabular}

** Significant at $\mathrm{P} \leq 0.05$ and $\mathrm{P} \leq 0.01$, respectively; ${ }^{\mathrm{ns}}$ Not significant 
As regards the prediction of mortality using ANN, experience in duck rearing $(0.422)$, primary occupation (0.315), source of foundation stock $(0.125)$, land holding (0.082) and management system $(0.057)$ were the five parameters of utmost importance (Table 9). The association between the observed and the predicted hatchability and mortality in form of a linear regression using
ALM is shown in Figures 1 and 2. The correlation coefficients ( $r=0.649$ vs 0.613$)$ were fairly high, while moderate coefficients of determination $\left(\mathrm{R}^{2}\right.$ $=0.422$ vs 0.376$)$ and Adjusted $\mathrm{R}^{2}(0.417$ vs 0.371 ) estimates were obtained for hatchability and mortality. The root mean square errors (RMSE) of 2.12150 and 2.22431 and akaike's information criterion corrected (AICC) values of

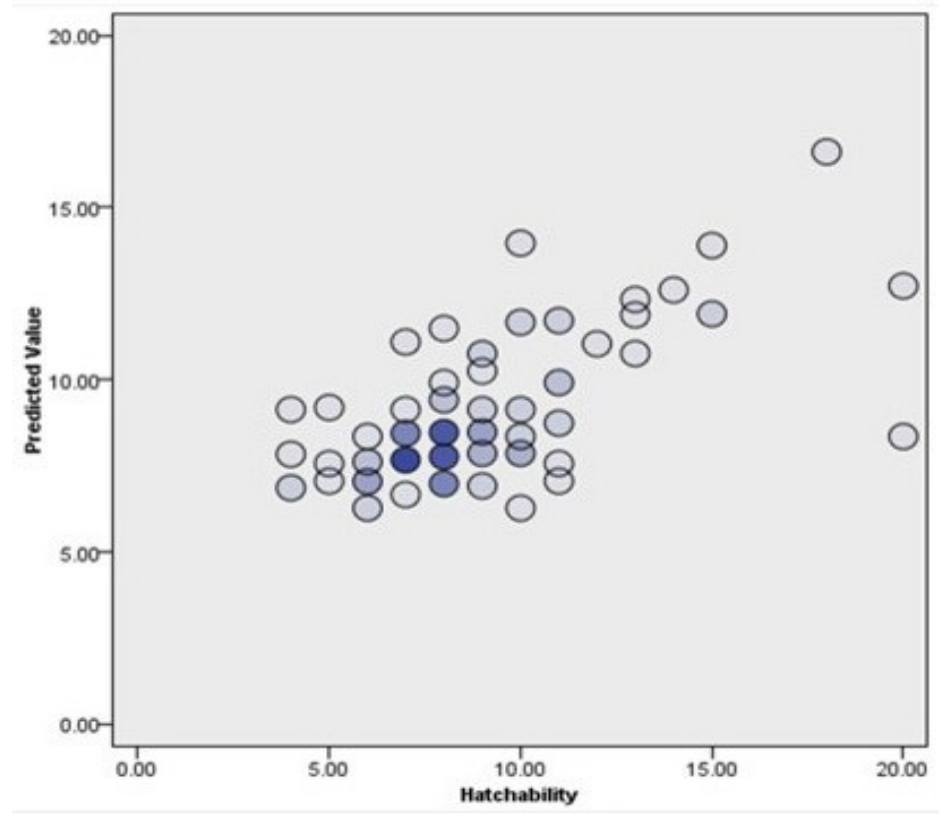

Figure 1. The Ccatter Plot of the Predicted and Observed Hatchability using ALM

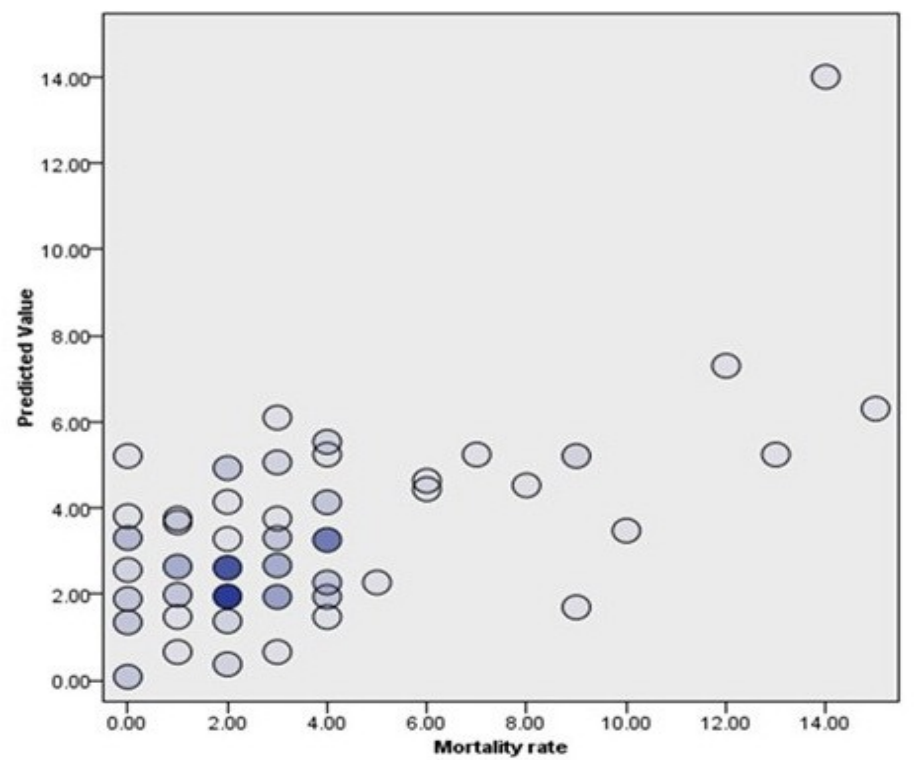

Figure 2. The Distribution Plot of the Predicted and Observed Mortality using ALM 
187.519 and 203.261 for hatchability and mortality, respectively in the ALM models were very low.

Different patterns were obtained under the ANN models as regards the prediction of hatchability and mortality, where $\mathrm{r}=0.757 \mathrm{R}^{2}=$ 0.573; Adjusted $\mathrm{R}^{2}=0.569$ and RMSE was 1.82357 (hatchability) (Figure 3); $\mathrm{r}=0.784 \mathrm{R}^{2}=$ 0.615 ; Adjusted $\mathrm{R}^{2}=0.612$ and $\mathrm{RMSE}$ was
1.75277 (mortality) (Figure 4).

\section{DISCUSSION}

Muscovy duck is one of the meat-producing livestock (Susanti and Purba, 2017). The preponderance of women farmers agrees with the general assertion that smallholder poultry is to a large extent under the control of the women folks. The flock size obtained in the present study is

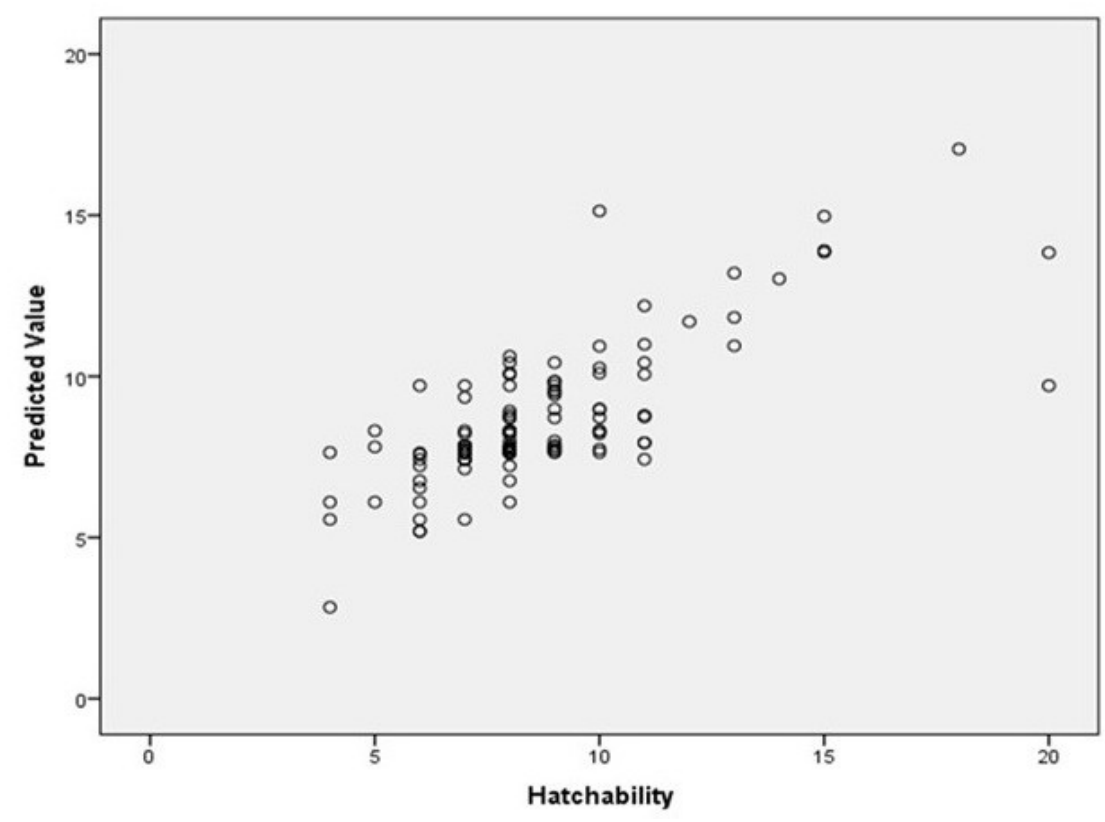

Figure 3. The Scatter Plot of Observed and Predicted Hatchability using ANN

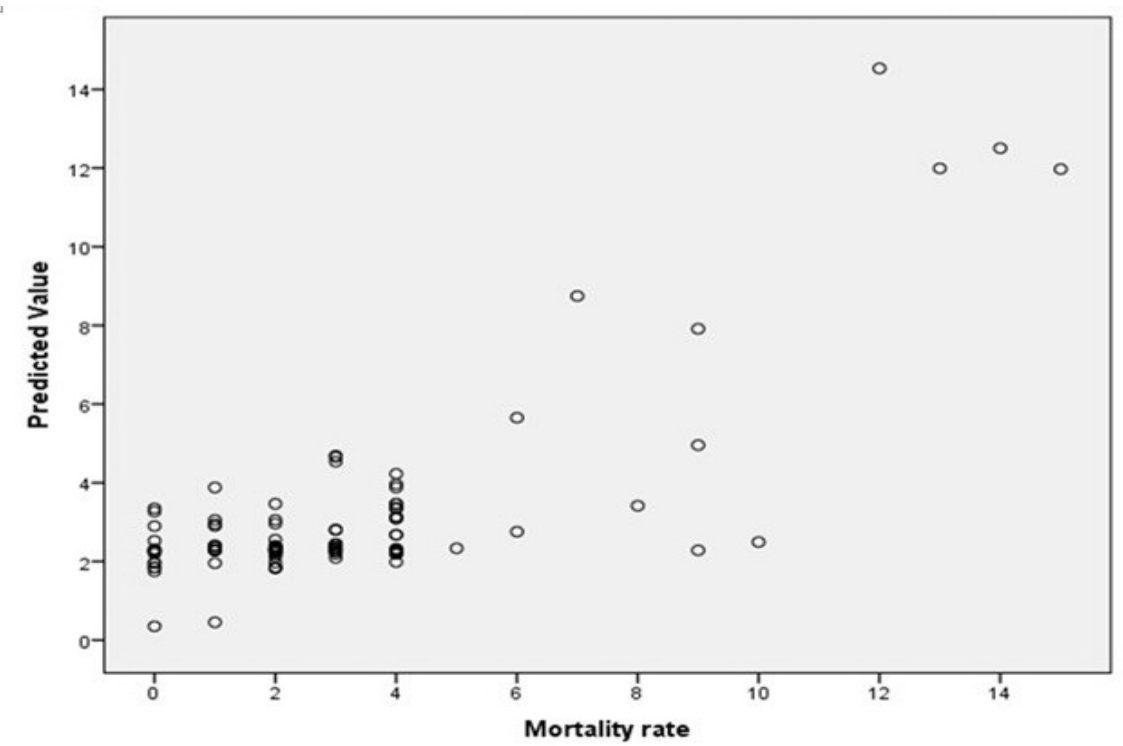

Figure 4. The Scatter Plot of Observed and Predicted Mortality Number using ANN 
Table 2. Flock Structure of Muscovy Ducks Kept in Nasarawa State

\begin{tabular}{lcccc}
\hline \multicolumn{1}{c}{ Parameter } & Minimum & Maximum & Mean & Standard error \\
\hline Flock size & 1.00 & 47.00 & 9.84 & 0.60 \\
Adult males number & 0.00 & 10.00 & 1.85 & 0.14 \\
Adult females number & 0.00 & 15.00 & 2.63 & 0.22 \\
Growers male number & 0.00 & 15.00 & 1.48 & 0.19 \\
Growers female number & 0.00 & 6.00 & 1.36 & 0.15 \\
Male ducklings & 0.00 & 7.00 & 1.27 & 0.18 \\
Female ducklings & 0.00 & 6.00 & 1.33 & 0.16 \\
\hline
\end{tabular}

higher than the $7.7 \pm 3$ ducks per unit reported by Banga-Mboko et al. (2011). The average eggs per clutch obtained in the current study appear low when compared with values reported by earlier researchers. Etuk et al. (2011) reported 16.23, 18.73 and 19 , respectively as average eggs per clutch while values ranging from 16-20, 16.4, 16.28 and 18 were reported by Adeyemi et al. (2008), Nwanta et al. (2006), Ola (2000) and Chia and Momoh (2012), respectively. The difference between their findings and that of the current study may largely be attributed to genetic factor, varying management systems and the periods records were taken. However, there is need for improved management practices by farmers in Nasarawa State to guarantee higher egg production. The low number of farmers that use herbs to treat their ducks in the present study is an indication of poor knowledge on the use of ethnoveterinary medicine.

Muscovy duck represents a suitable model for hypothesis testing in breeding biology of waterfowl under natural incubation; reproductive consequences of eggs laid can best be assessed through the number of eggs hatched. The current findings are congruous to the findings of Oguntunji and Ayorinde where majority (44.5\%) of the respondents indicated that female ducks underwent two reproductive cycles in a year. Muscovy ducks are very good setters, capable of hatching 12-15 duck eggs. The hatchability value of the present study (about 88\%) appears higher than the values reported for between normal (76\%) and dump nests (77\%) genetically unselected variety of Muscovy duck in Mozambique (Harun et al., 1998), 70.7\% and $69.7 \%$ reported by Widiyaningrum et al. (2016) and $54.21 \%$ reported by Rashid et al. (2009).
Similar hatching rate above $80 \%$ with that of the current study has been reported (Oguntunji and Ayorinde, 2015).

The higher hatchability recorded in the wet season is an indication of the degree of environmental comfort experienced by birds. This is in consonance with the report of Widiyaningrum et al. (2016) that environmental factors such as temperature and humidity are important for successful hatching. Our observation, however, is contrary to the report of Boonprong (2000), where hatchability was highest in winter followed by summer and rainy season, respectively. Harsh environmental factors (e.g. temperature, humidity, turning etc.) might be causes of higher mortality in the hot-dry season as observed in the current study. Heat stress made birds to pant and could result in heat stroke and mortality. It has been reported that extremes temperatures could be experienced in the hot-dry season in North Central Nigeria (Yakubu et al., 2018a), thereby making the birds uncomfortable. Such heat stressed birds could experience high rate of mortality and morbidity (Nidamanuri et al., 2017). According to Shittu et al. (2014), hotdry climatic environment is characterized by heat stress, inefficiency in the usage of feed and waning immunity, thereby leading to high mortality.

To the best of our knowledge, the present study appears as the first to predict hatchability and mortality rate of Muscovy ducks in Nigeria using robust algorithms such as ALM and ANN. Application of appropriate models to approximate the performance function warrants more precise prediction and helps to make the best decisions in the poultry industry. The better predictive ability of ANN in the present study could be as a result 
Table 3. Management of Muscovy ducks Kept in Nasarawa State

\begin{tabular}{|c|c|c|c|}
\hline Characteristics & No $(\%)$ & Chi-square & P-value \\
\hline \multicolumn{4}{|l|}{ Categorical variables } \\
\hline \multicolumn{4}{|l|}{ Source of Foundation Stock } \\
\hline Inherited & $13(10.9)$ & & \\
\hline Purchase from market & $79(66.4)$ & & \\
\hline Purchase from neighbor & $25(21.0)$ & & \\
\hline Borrowed & $\begin{array}{ll}0 & (0.0)\end{array}$ & & \\
\hline Others & $2(1.7)$ & 117.605 & $0.01 * *$ \\
\hline \multicolumn{4}{|l|}{ Management system } \\
\hline Semi-intensive & $86(72.3)$ & & \\
\hline Intensive & $22(18.5)$ & & \\
\hline Extensive & $11(9.2)$ & 82.706 & $0.01 * *$ \\
\hline \multicolumn{4}{|l|}{ Breeding Control } \\
\hline No & $118(99.2)$ & & \\
\hline Yes & $1(0.8)$ & 115.034 & $0.01 * *$ \\
\hline \multicolumn{4}{|l|}{ Access to Vet } \\
\hline No & $60(50.4)$ & & \\
\hline Yes & $59(49.6)$ & 0.008 & $0.927^{\mathrm{ns}}$ \\
\hline \multicolumn{4}{|l|}{ Vet Category } \\
\hline Government Vet & $20(16.8)$ & & \\
\hline $\begin{array}{l}\text { Private Vet } \\
\text { Self medication }\end{array}$ & $\begin{array}{r}33(27.7) \\
6 \quad(5.0)\end{array}$ & 53.269 & $0.01 * *$ \\
\hline \multicolumn{4}{|l|}{ Use of herbs } \\
\hline Yes & $7(5.9)$ & & \\
\hline No & $112(94.1)$ & 92.647 & $0.01 * *$ \\
\hline \multicolumn{4}{|l|}{ Continuous variables } \\
\hline No of foundation stock & $\begin{array}{l}\text { Mean } \\
2.29\end{array}$ & $\begin{array}{c}\text { Standard error } \\
0.11\end{array}$ & \\
\hline
\end{tabular}

** Significant at $\mathrm{P} \leq 0.01$, respectively; ${ }^{\text {ns }}$ Not significant

of its sensitivity to non-linear dynamics. Therefore, it could serves as a veritable means of forecasting incubation performance in Muscovy ducks. This is in consideration of its robustness in tackling noisy input data, high tolerance to faults and dimensionality problem and generalization from the input data. According to Bolzan et al. (2008), ANN model outperformed its multiple linear counterpart in the prediction of hatched eggs. Mehri (2013) reported ANN-based model with a better accuracy $\left(\mathrm{R}^{2}=0.99\right)$ than that obtained in the present study. However, the difference might be attributed to the use of egg main physical characteristics as input variables in the earlier study as against socio-economic factors in the present study. Chamsaz et al. (2011) reported that the ANN produced more accurate predictions of hatchability than the linear regression equation $\left(\mathrm{R}^{2}=0.9984\right.$ versus 0.4003$)$. It is, therefore, possible to elucidate the performance variables of birds using ANN as it facilitates scientific and objective decision making including the simulations (Salle et al., 2003) of the consequences related to such decisions. When the current knowledge is applied to the present study, it could guide management decisions and strategies geared towards boosting production duck production. In a related study in 
Table 4. Productivity Indices of Muscovy Ducks Kept in Nasarawa State

\begin{tabular}{lcccc}
\hline \multicolumn{1}{c}{ Parameter } & Minimum & Maximum & Mean & Standard error \\
\hline Continuous variables & & & & \\
Age of duck at first lay (months) & 4.00 & 9.00 & 5.51 & 0.07 \\
Clutch number per year & 2.00 & 3.00 & 2.84 & 0.03 \\
Egg number in a clutch & 5.00 & 22.00 & 9.87 & 0.26 \\
Brooding length (weeks) & 4.00 & 5.00 & 4.68 & 0.04 \\
Egg number hatched in a clutch & 4.00 & 20.00 & 8.66 & 0.25 \\
Mortality rate per annum & 0.00 & 15.00 & 2.95 & 0.26 \\
Mortality male duckling & 0.00 & 5.00 & 1.03 & 0.10 \\
Mortality female duckling & 0.00 & 5.00 & 0.79 & 0.10 \\
Mortality grower male & 0.00 & 4.00 & 0.37 & 0.07 \\
Mortality grower female & 0.00 & 3.00 & 0.31 & 0.06 \\
Mortality adult male & 0.00 & 3.00 & 0.26 & 0.05 \\
Mortality adult female & 0.00 & 4.00 & 0.34 & 0.06 \\
Categorical variables & & & & \\
& No (\%) & Chi-square & P-value & \\
Season of highest hatchability & & & & \\
Wet & $117(98.3)$ & & & \\
Hot-dry & $2(1.7)$ & & & \\
Harmatan & $0(0.0)$ & 111.134 & $0.01 * *$ & \\
Season of highest mortality & $5(4.2)$ & & & \\
Wet & $103(86.6)$ & & & \\
Hot-dry & & & & \\
Harmatan & & & & \\
\hline
\end{tabular}

Table 5. Descriptive Statistics of the Observed and Predicted Hatchability and Mortality Rates

\begin{tabular}{lcccc}
\hline \multicolumn{1}{c}{ Parameter } & Minimum & Maximum & Mean & Standard deviation \\
\hline Hatchability & & & & \\
$\quad$ Observed & 4.00 & 20.00 & 8.66 & 2.78 \\
ALM Predicted & 6.26 & 16.61 & 8.66 & 1.80 \\
ANN Predicted & 2.83 & 17.06 & 8.65 & 2.12 \\
Mortality & & & & \\
Observed & 0.00 & 15.00 & 2.95 & 2.80 \\
ALM Predicted & -0.11 & 14.00 & 2.95 & 1.72 \\
ANN Predicted & 0.35 & 14.53 & 3.03 & 2.14 \\
\hline
\end{tabular}


Table 6. Fractional Importance of Some Variables to the Prediction of Hatchability using Automatic Linear Modelling

\begin{tabular}{lccc}
\hline \multicolumn{1}{c}{ Model term } & Coefficient & Significance (p-value) & Importance \\
\hline Intercept & 5.871 & 0.000 & \\
Experience in duck rearing & 0.392 & 0.000 & 0.724 \\
Educational status & 2.020 & 0.004 & 0.156 \\
Source of foundation stock & 0.903 & 0.059 & 0.067 \\
Season of hatchability & 2.652 & 0.094 & 0.053 \\
\hline
\end{tabular}

Table 7. Fractional Importance of Some Variables to the Prediction of Mortality using Automatic Linear Modelling

\begin{tabular}{lccc}
\hline \multicolumn{1}{c}{ Model term } & Coefficient & Significance (p-value) & Importance \\
\hline Intercept & 0.898 & 0.273 & \\
Primary occupation & 10.336 & 0.000 & 0.395 \\
Source of foundation stock & 2.060 & 0.003 & 0.183 \\
Experience in duck rearing & 0.192 & 0.005 & 0.164 \\
Land holding & -1.201 & 0.009 & 0.138 \\
Management system & 1.804 & 0.015 & 0.121 \\
\hline
\end{tabular}

Table 8. The Importance of Independent Variables in the Prediction of Hatchability using Artificial Neural Network

\begin{tabular}{lcc}
\hline \multicolumn{1}{c}{ Variables } & Importance & Normalized importance (\%) \\
\hline Experience in duck rearing & 0.387 & 100.0 \\
Source of foundation stock & 0.320 & 82.6 \\
Educational status & 0.148 & 38.3 \\
Season of hatchability & 0.144 & 37.3 \\
\hline
\end{tabular}

humans, high accuracy was obtained in the prediction of mortality using ANN model (Shi et al., 2012) while ANN has also been used to detect chicken growth anomaly from mortality rate and feed conversion ratio (Purnomo et al., 2018).

\section{CONCLUSION}

The predicted hatchability and mortality mean values using both ALM and ANN algorithms were similar to their respective observed values. Considering the moderate to high variation explained by ANN and ALM models in the prediction of hatchability and mortality rates, they appear to be reliable. Therefore, the two models could be recommended as veritable tools for the prediction of hatchability and mortality rates in ducks. Such prediction will aid management decisions to improve flock size and the associated profitability of the farm. 
Table 9. The Importance of Independent Variables in the Prediction of Hatchability using Artificial Neural Network

\begin{tabular}{lcc}
\hline \multicolumn{1}{c}{ Variables } & Importance & Normalized importance (\%) \\
\hline Experience in duck rearing & 0.387 & 100.0 \\
Source of foundation stock & 0.320 & 82.6 \\
Educational status & 0.148 & 38.3 \\
Season of hatchability & 0.144 & 37.3 \\
\hline
\end{tabular}

\section{REFERENCES}

Adeyemi, O.A., R.A. Sobayo and F.A. Aluko. 2008. A survey of duck farming activities in Abeokuta metropolis of Ogun State, Nigeria. Nig. Poult. Sci. J. 5(1):23-29.

Ahmad, H.A. 2011. Egg production forecasting: Determining efficient modeling approaches. J. Appl. Poult. Res. 20(4):463-473.

Akil, L. and H.A. Ahmad. 2016. Salmonella infections modelling in Mississippi using neural network and geographical information system (GIS). BMJ Open. 6(3):e009255.

Banga-Mboko, H., D. Maes and P. L. Leroy. 2007. Indigenous Muscovy ducks in CongoBrazzaville. I. A survey of indigenous Muscovy duck management in households in Dolisie city. Trop. Anim. Health Prod. 39(2):115-122.

Bolzan, A.C., R.A.F. Machado and J.C.Z. Piaia. 2008. Egg hatchability prediction by multiple linear regression and artificial neural networks. Braz. J. P. Sci. 10:97-102.

Boonprong, S., S. Trimanee and P. Nuchsai. 2000. Influence of breed and season on Muscovy duck eggs hatchability. http://agrid.fao.org/agris-search/search.do? recordID $=\mathrm{TH} 2002002002518$.

Chamsaz, M., A.H. Perai, S. Asadpour and R.H. Shahidi. 2011. Comparison of the 3-phase segmented linear regression and artificial neural network models to predict broiler hatchability. J. Appl. Poult. Res. 20(4):447453.

Chia, S. S. and O. Momoh. 2012. Some physical and reproductive characteristics of Muscovy ducks (Cairinamoschata) under free range management system in two locations in Benue State of Nigeria. In: Proceedings 37th Annual Conference of Nigerian
Society for Animal Production. pp. 20-23.

Etuk, I.F., G.S. Ojewola, S. Akomas, E.B. Etuk and I.P. Ogbuewu. 2011. Egg production potentials of Muscovy ducks (Cairina moschata) raised under three management systems in the humid tropics. Nig. J. Anim. Sci.13: https://www.ajol.info/index.php/ /tjas/article/view/ 80094

Etuk, I.F., G.S. Ojewole and S.F. Abasiekong. 2006. Performance of Muscovy ducks under three management systems in Southeastern Nigeria. Int. J. Poult. Sci. 5(5):474-476.

Gómez, L.F., L.A. Ríos-Osorio and M.L. Eschenhagen-Durán. 2016. Key Concepts of Agroecology Science. A Systematic Review. Trop. Subtrop. Agroecosys. 19:109-117.

Hassan, W.A. and M.S. Muhammad. 2003. Ecotypes of the Muscovy in the Northwest of Nigeria: variation in body weight and bill length. In: Proceedings Annual Conference of Animal Science Association of Nigeria (ASAN), September 16-18 Federal University of Technology, Minna, Niger State, Nigeria. pp. 23-24.

Harun, M.A.S., R.J. Veeneklaas, M. Van Kampen, and M. Mabasso. 1998. Breeding biology of Muscovy duck Cairina moschata in natural incubation: The Effect of nesting behavior on hatchability. Poultr Sci. 77:1280-1286.

Johari, S., N. D. Kusumadani and E. Kurnianto. 2013. Multivariate analysis of the morphological traits of female duck, muscovy-duck and mule-duck. J. Indonesian Trop. Anim. Agric. 38(3):143148.

LaFaro, R.J., S. Pothula, K.P. Kubal, M.E. Inchiosa, V.M. Pothula, S.C. Yuan, D.A. Maerz, L. Montes, S.M. Oleszkiewicz, A. Yusupov, R. Perline and M.A. Inchiosa Jr. 2015. Neural network prediction of ICU length of stay following cardiac surgery 
based on pre-incision variables. PLoS ONE 10(12): $\mathrm{e} 0145395$.

Lyam, A. 2000. Nasarawa State. In: [Mamman, A.B., Oyebanji, J.O. and Peters, S.W. (eds)], Nigeria: A People United, a Future Assured. Survey of States, Vol. 2(2), Federal Ministry of Information, Abuja.

Mehri. M. 2013. A comparison of neural network models, fuzzy logic, and multiple linear regression for prediction of hatchability. Poult. Sci. 92(4):1138-1142.

NBS (National Bureau of Statistics). 2012. National Bureau of Statistics/ Federal Ministry of Agriculture and Rural Development Collaborative Survey on National Agriculture Sample Survey (NASS), 2010/2011-Draft Report. May, 2012.

Nidamanuri, A.L., S. Murugesan and R.K. Mahapatra. 2017. Effect of heat stress on physiological parameters of layers-a review. Int. J. Livest. Res. 7:1-17.

Nwanta, J.A., J.U. Umoh, P.A. Abdu, I. Ajogi and J.K. Ali-Balogun. 2006. Management of losses and Newcastle disease in rural poultry in Kaduna State. Nig. J. Anim. Prod. 33(2):274-285.

Oguntunji, A.O. and K.L. Ayorinde. 2015. Health management practices and reproductive performance of ducks in Nigeria. J. Agric. Sci. 60 (3):325-337

Oguntunji, A.O. 2013. Phenotypic and Biochemical characterization of the Nigerian Muscovy duck (Cairina moschata). Ph.D. Thesis, Bowen University, Iwo, Osun State, Nigeria.

Ola, S.I. 2000. Vital reproductive and productive characteristics of the Nigerian Muscovy ducks. In: Proceedings $25^{\text {th }}$ Annual Conference of Nigerian Society of Animal Production (NSAP), 19-23 March, Umudike, Abia State. pp. 188-190

Purnomo, H.D., R. Somya and C. Fibirani. 2018. Artificial neural network for chicken growth anomaly detection. Int. J. Adv. Comp. Eng. Network. 6(3):26-29.

Rashid, M.A., M.H. Kawsar, M.A. Rashid, M.Y. Miah and M.A.R. Howlider. 2009. Fertility and hatchability of Pekin and Muscovy duck eggs and performance of their ducklings. Progress. Agric. 20(1 \& 2):93 98.

Salle, C.T.P., A.S. Guahyba, V.B. Wald, A.B.
Silva, F.O. Salle and V.P. Nascimento. 2003. Use of artificial neural networks to estimate production variables of broilers breeders in the production phase. Brit. Poult. Sci. 44:211-217.

Shi, H-Y., K-T. Lee, H-H. Lee, W-H. Ho, D-P. Sun, J-J. Wang and C-C. Chiu. 2012. Comparison of artificial neural network and logistic regression models for predicting inhospital mortality after primary liver cancer surgery. PLoS ONE 7(4):e35781.

Shittu, A., A.A. Raji, S.A. Madugu, A.W. Hassan and F.O. Fasina. 2014. Predictors of death and production performance of layer chickens in opened and sealed pens in a tropical savannah environment. BMC Vet. Res. 10:214.

SPSS. 2015. Statistical Package for Social Sciences. SPSS Inc., 444 Michigan Avenue, Chicago, IL60611

Susanti, T. and M. Purba. 2017. The growth of local white Muscovy growth during starter and grower periods. J. Ilmu Ternak Vet. 22(2):63-67.

Widiyaningrum, P., Lisdiana and N.R. Utami. 2016. Egg production and hatchability of local ducks under semi intensive vs extensive managements. J. Indonesian Trop. Anim. Agric. 41(2):77-82.

Yakubu, A., O.I.A. Oluremi and E.I. Ekpo. 2018a. Predicting heat stress index in Sasso hens using automatic linear modeling and artificial neural network. Int. J. Biometeorol. 62(7):1181-1186.

Yakubu, A., O.I.A. Oluremi and Z.N. Ibrahim. 2018b. Modelling egg production in Sasso dual-purpose birds using linear, quadratic, artificial neural network and classification regression tree methods in the tropics. Livest. Res. Rural Devel. 30(10).

Yakubu, A. 2013. Characterization of the local Muscovy duck genetic resource of Nigeria and its potential for egg and meat production. World's Poult. Sci. J. 69:931938.

Yakubu, A., F.G. Kaankuka and S.B. Ugbo. 2011. Morphometric traits of Muscovy ducks from two agro-ecological zones of Nigeria. Tropicultura. 29(2):121-124.

Yakubu, A. 2010. Indigenous chicken flocks of Nasarawa State, north central Nigeria: Their characteristics, husbandry and productivity. Trop. Subtrop. Agroecosyst. 12(1):69-76. 